\title{
IMPLEMENTING THE GAMIFICATION LEARNING METHOD TO IMPROVE LEARNING RESULTS OF ADJUSTING JOURNAL
}

\author{
IMPLEMENTASI METODE PEMBELAJARAN GAMIFIKASI UNTUK \\ MENINGKATKAN HASIL BELAJAR JURNAL PENYESUAIAN \\ By : \\ Nur Hida Aulia Majid \\ Accounting Education Study Program Yogyakarta State University \\ nurhida.nha@gmail.com

\section{Endra Murti Sagoro} \\ Lecturer in Accounting Education Department Yogyakarta State University \\ endra.murti@gmail.com
}

\begin{abstract}
This study aims to improve Cognitive Learning Results of Adjusting Journal through implementing The Gamification Learning Method. The study also test the effectiveness of gamification learning method compare with teacher-centered. The subject of this study were 30 students of grade X Accounting 2 of SMK Negeri 1 Wonosari in the academic year of 2017/2018. This was an Experimented Classroom Action Research conducted in two cycles. The data was collected through tests, field notes, observation, and documentation. Data analysis used were independent sample t-test, paired sample t-test, descriptive data analysis of quantitative and qualitative. Based on the results of research, implementing The Gamification Learning Methods can improve Learning Results of Adjusting Journal. It can be seen from the average percentage of pre-test results 48.27, post-test I 64.57 and post-test II to 80.27 at significance value of 0.000 . The Gamification Learning Method is also more effective than the teacher-centered method as shown by Independent Sample T-Test at significance value of 0.031 .
\end{abstract}

Keywords: Gamification Learning Method, Learning Results, CAR

\begin{abstract}
Abstrak
Penelitian ini bertujuan untuk meningkatkan Hasil Belajar jurnal penyesuaian melalui implementasi Metode Pembelajaran Gamifikasi. Selain itu, penelitian juga menguji keefektifan penggunaan metode pembelajaran Gamifikasi dibandingkan dengan metode ceramah. Subjek penelitian adalah 30 siswa kelas X Akuntansi 2 SMK Negeri 1 Wonosari tahun ajaran 2017/2018. Jenis penelitian yaitu Penelitian Tindakan Kelas Eksperimen yang dilaksanakan dalam dua siklus. Teknik pengumpulan data melalui tes, catatan lapangan, observasi, dan dokumentasi. Analisis data yang digunakan yaitu analisis uji independent sample t-test, paired sample t-test, data deskriptif kuantitatif dan kualitatif. Berdasarkan hasil penelitian, implementasi Metode Pembelajaran Gamifikasi dapat meningkatkan Hasil Belajar jurnal penyesuaian. Hal ini terlihat dari kenaikan persentase rata-rata hasil pre-test sebesar 48,27, post-test I 64,57 dan post-test II menjadi 80,27 pada tingkat signifikansi sebesar 0,000. Implementasi metode pembelajaran Gamifikasi juga lebih efektif jika dibandingkan dengan
\end{abstract}


metode ceramah dibuktikan uji Independent Sample T-Test pada tingkat signifikansi sebesar 0,031 .

Kata kunci: metode pembelajaran Gamification, hasil belajar, PTK

\section{INTRODUCTION}

Accounting as the language of the business world is an information system that provides reports on the activities and economic conditions of the company as an appropriate decision-making step for the stakeholders (Reeve et al, 2013: 9). Accurate financial information is not only for national or multinational enterprises, but the whole society also needs financial statements. This shows the magnitude of the needs and opportunities for someone who has the ability to prepare financial statements.

Preparation of financial statements cannot be made by any party, they need education and training, so that financial information is not misleading. This ability can be obtained by the community through formal and nonformal education, as confirmed by Nurhayati (2015: 10) in the conclusion of her research that education and training in the field of accounting have a significant effect on the accounting information generated. Education and training in accounting are organized by vocational high schools (VHS) areas of business and management expertise. One of the vocational high schools in Gunungkidul which opens accounting majors is SMK N 1 Wonosari.

Based on the preliminary observations, the teacher explained that the 2013 curriculum requires grade $\mathrm{X}$ students pass the basic competencies to prepare the financial statements of service companies. In fact, the students of grade $\mathrm{X}$ accounting majors were not familiar with the terms of basic accounting equations and credit debit mechanisms. Students tend to memorize more without understanding the meaning of the material. The tendency to memorize can be seen from the answers that are almost similar to the module and lack of analysis for account classification and kredit debit mechanism. They have not been able to relate what had been learned to how the knowledge was applied. In addition, students had a low interest in accounting subjects because of several factors among them had felt the wrong vocational, attended program at requests of parents, tired of the many tasks, and bored because every meeting last for 5 hours. When the teachers were explaining, students did not a pay attention, talking with colleagues, daydreaming, drawing, playing mobile phone, and ignoring the assignment given if it is not rated. The interest of students to learn accounting subject was low, so its influenced the learning results. It proved by the fact that as many as $50 \%$ of students have not been completed in the competence to understand the stages of the accounting cycle. The high percentage shows that improving the ability of accounting students is very necessary especially for grade $\mathrm{X}$. They are in the stage of establishing a strong foundation of accounting science to facilitate the next learning. The next level of subject matter will be more difficult and related to the previous material, especially in adjustment entries competency. This competency is in desperate need of reasoning. Adjusting entries require students to establish recognition of income and expenses in the year. The improvement of student ability in the form of learning results can be pursued through improving the quality of the learning process.

The learning process according to Dwi Siswoyo (2013: 72) is an interaction between students, teachers, and educational goals or called the three central components of the education system. The successfull learning process needs the effort that support the process. One of them through the utilization of various methods and instructional media as supporting the achievement of educational 
purposes. Implementation of learning methods and media by teacher in grade $\mathrm{X}$ AK 2 was used the teacher-centered methods. Learning methods will affect the student learning results. According to Mahmood, appropriate methods and techniques in learning can make less intelligent students easier to learn (Eneogu \& Ejimonye, 2014: 165). The right method is able to accommodate most of the students' needs during the learning process.

Various methods of learning have been developed in previous research in line with the emergence of various media. The gamification learning method becomes an appropriate choice to improve learning results for grade $\mathrm{X}$ accounting student of SMK N 1 Wonosari. Gamification methods allow students to learn interactively, so can support the learning process (Handani, 2015). Gamification designs work processes using game mechanisms for fun experiences (Wood \& Reiners, 2015: 3039). Teachers can direct students to multiple exercise through the game mechanism, such as who wants to be a millionaire, jeopardy, bingo, etc. This mechanism provides students to challenge the exercise and drive to win (Moncada \& Moncada, 2014). Fun learning will generate motivation to learn and will lead to improved learning results for grade $\mathrm{X}$ accounting students. Gamification is able to add a variety of teachers and meet the needs of meaningful learning methods. This method is able to improve students' interest and understanding of subjects so that learning results can be improved (Jusuf, 2016).

Based on background mentioned, in this case, the researcher interested in researching "Implementing The Gamification Learning Method to Improve Learning Result of Adjusting Journal at Grade X Accounting 2 Students of SMK Negeri 1 Wonosari in the Academic Year of 2017/2018". In addition, it can add teacher references in the use of learning methods. Learning results according to Sukiman (2011: 11-13) is a form of learning and teaching objectives that are cognitive, affective, and psychomotor. The learning results in this study are the students' ability after they receive their learning experience and are not limited to score but include qualitative assessment. The study was limited to cognitive learning results. The results of cognitive learning are demonstrated through students' ability to apply analyzes and make adjusting entries.

Gamification is a unity between the elements and the mindset of the game used not in the context of the game (Hunter, 2012). Gamification Learning Method is a learning process that uses the game mechanism for education content as a step to grow motivation. The game mechanism in gamification to ensure the emergence of a sense of fun by students' millennial generation (Schnepp, 2014: 2-5). The success of this method when students are able to improve their skills.

\section{RESEARCH METHOD Type of The Research}

This study aims to improve the cognitive learning results of grade $\mathrm{X}$ accounting students through gamification learning methods so that Classroom Action Research (CAR) is appropriate because it can improve the previous learning mechanism. Classroom action research serves to enhance professional skills, teacher knowledge, and improve processes and educational results (Lodico, 2010). According to Geoffrey E. Mills (2014: 8), CAR can make positive learning changes through the inquiry process deliberately given by the teacher when teaching. 
The classroom action research model used is the research model of Kemmis and Taggart (Arikunto, 2015). Each of CAR cycle through four stages, namely planning, implementation, observation, and reflection on the action. Action research must be at least two consecutive cycles of action.

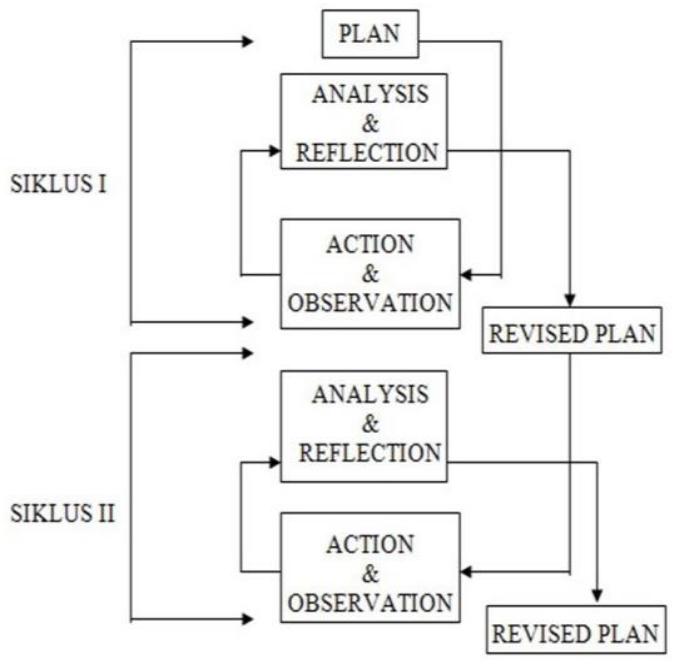

Figure 1. Classroom Action Research Cycle (Arikunto, 2015:143-144)

\section{Setting of The Research}

This research was conducted in grade $\mathrm{X}$ Accounting 2 students of SMK Negeri 1 Wonosari in The Academic Year of 2017/2018 which is located at Jl. Veteran Wonosari, Gunungkidul, Yogyakarta. The research was conducted in the month February-March 2018, with planning stage at the end of February 2018. While the stage of action, observation, and reflection was conducted in early March 2018.

\section{Research Subject and Object}

The research subjects were grade $X$ Accounting 2 students of SMK Negeri 1 Wonosari in the academic year of 2017/2018 consisting of 30 students. The object was the cognitive learning result of adjusting journal through implementation of Gamification Learning Method.

\section{Research Procedures}

The research was conducted in two cycles with one session each cycle. The following are the research steps for each cycle:

1. Cycle I

a. Action Planning

Planning undertaken in classroom action research includes:

1) Developing Lesson Plan (LP) for basic competencies record in adjusting journal using Gamification Learning Method,

2) Developing research instruments in the form of pre-test and post-test to know the improvement of student learning results,

3) Designing the gamification activity to be used and adapted to 11 design characteristics according to Moncada (2014: 12). Gamification on cycle 1 using card UNO develop by Nurul Hikmah (2017) and fun with accounting application developed by Adetia Ratih (2017). Card UNO consist of materials, question, and answer cards. Fun with accounting application is accounting games based on RPG maker that consist of the service enterprise accounting cycle. The player will bring different missions to meet with the king and through various question obstacles. These games are suitable and easy to apply in the competency of adjusting entries to multiply the exercise.

4) Preparing the format of observation sheets, observation guides, and field notes,

5) Preparing student worksheets,

6) Establishing indicators of achievement.

b. Implementation of Action

The researcher carried out the action of learning using Gamification Learning Method guided by LP. The researcher gave the pre-test to the student before applying the method. A 
pretest was also given to students of other classes. This implementation was tailored to the field conditions. At the end of the execution, students were given a post-test to determine the ability to record in the adjusting journal.

c. Observation of Action

This process was carried out simultaneously with the implementation of the action by observing and recording the activities of Gamification Learning Methods on planned accounting lessons. Researcher looked for the student response in the implementation of these methods, so that obtained the necessary data such as changes in the student ability.

d. Reflection Action

Reflection action was done by analyzing the data that have been collected in the previous process In addition, the results of pretest and posttest score were also processed to see the improvement of students' ability. The results of the conclusions are used as the basis for improvement of cycle II.

2. Cycle II

a. Action Planning

Planning began by making an LP for basic competencies recorded in adjusting entries using gamification learning methods that have been adapted to first cycle reflections. Gamification would applied adapting Jeopardy Games and bingo games. Jeopardy is a 1964 game show that has a unique answer. Participants must select one of the given categories and level then answer. Bingo games are chosen because these games allow students to practice many questions. Students choose the numbers from 1 to 25 and then answer the question behind the number. Students who able to form the letter $\mathrm{B}-\mathrm{I}-\mathrm{N}-\mathrm{G}-\mathrm{O}$ is the winner. Presentation of jeopardy and BINGO games using Ms. Powerpoint

b. Implementation of Action

Implementation of the action in accordance with the planning contained in the LP. This implementation could be adjusted to existing field conditions. At the end of the action, the students were given a posttest to determine the students' ability to record adjusting entries

c. Observation of Action

This stage was done while learning takes place. The observation stage was to observe and record everything that happens during the action.

d. Reflection

This stage aims to determine whether there was an improvement in Accounting Learning Results compared to the results before the research cycle I until cycle II. If there is no improvement then the next cycle will be implemented.

\section{Data Collection Method and Instruments}

\section{Test Assessment}

The test was used to measure the ability of a student's respone to a number of questions that illustrated their ability to record competencies in adjusting entries. The test would be given in the form of a written test to accommodate a large number of students and have high objectivity. Test scoring techniques were given in the form of pre-test and post-test, so the difference in scores between the two shows the improvement and effectiveness of gamification learning methods. 


\begin{tabular}{|c|c|}
\hline KD & Indicators \\
\hline 3.10 & $\begin{array}{l}\text { 3.10.1. Able to explain the } \\
\text { definition of adjusting } \\
\text { entries } \\
\text { 3.10.2. Be able to identify } \\
\text { accounts that require } \\
\text { adjustings } \\
\text { 3.10.3. Be able to analyze the } \\
\text { effect of accounts on } \\
\text { adjusting entries }\end{array}$ \\
\hline 4.10 & $\begin{array}{l}\text { 4.10.1. Be able to analyze } \\
\text { transactions by adjusting } \\
\text { entries } \\
\text { 4.10.2. Be able to record } \\
\text { transactions entries }\end{array}$ \\
\hline
\end{tabular}

Table 1. Test Lattice Grid Source: Primary Data

2. Observation

Observation aimed to observe and record systematically the elements that appeared during the learning process with the participatory observation. The following aspects observed in accounting learning with gamification learning methods, including:

a. Attention students in following the learning activities,

b. Each student learns materials assigned to groups as well as individuals,

c. Each student is able to communicate well,

d. Each student helps each other's group,

e. Students are interactive,

f. Students are enthusiastic about the learning process,

g. Students do all the challenges

3. Field Records

Field notes are used by the researcher to describe the classroom atmosphere when the action was taken. All activities and events in the class had recorded in the field notes. The event could be an interaction between students with teachers and among students.

4. Documentation
Documentation aimed to provide an overview of how a classroom action research was conducted. Documentation used include photos, images, LP, pretest and posttest ratings.

\section{Data Analysis Technique}

The analysis technique used in this research is quantitative descriptive statistical data analysis.

1. Quantitative Data Analysis

a. Test Requirements for Data Analysis

Terms that must be analyzed based on the hypothesis that is formulated test the normality of data through the different test by independent sample ttest. The test was performed using a pretest data of the both classes. Different tests were performed using data processing application assistance. If empirical $t$ is greater than alpha $(0,05)$ so there is no a significant difference.

b. Hypothesis Testing

The hypothesis to be tested is the improvement of cognitive learning results at grade $\mathrm{X}$ Accounting 2 students of SMK N 1 Wonosari and the effectiveness the gamification learning method compared the teacher-centered method. Testing is done by way of calculating the average and achievement of student learning results based on MCC, paired sample t-test, and independent sample t-test. Data from learning result are calculated the average value by using formula (Sugiyono, 2015: 210):

$\mathrm{Me}=\frac{\sum X i}{N}$

Information :

$\mathrm{Me}=$ mean

$\sum X i=$ sum of all values

$\mathrm{N}=$ number of individuals

The calculation of the percentage of students who reach the limit of completeness is using this formula (Trianto, 2012: 63-64):

$\mathrm{P}=\frac{F}{N} \times 100 \%$

Information : 
$\mathrm{P}=$ Percentage of completed students

$\mathrm{F}=$ Number of students who score $>75$

$\mathrm{N}=$ Number of students taking the test

Observation data were analyzed to determine the percentage of students' respone scores on cooperative learning method based on gamification (Sugiyono, 2015):

a. Defining scoring criteria

b. Summing up the scores of behaviors that appear

c. Calculating the score of student observation result by formula

Percentage of student respone scores per indicator

Value $=\frac{\text { Student interest score }}{\text { maximum score per student }} \times 100 \%$

The data has been obtained will be searched for the percentage improvement of student learning results with the formula $=\mathrm{B}-\mathrm{A}$

\section{Successful Action Criteria}

Table 2. The Categories Indicator Modified

\begin{tabular}{|c|c|c|c|}
\hline $\begin{array}{c}\text { The } \\
\text { Interval }\end{array}$ & $\mathrm{F}$ & $(\%)$ & $\begin{array}{c}\text { The } \\
\text { Tendency }\end{array}$ \\
\hline$<75$ & 25 & $83,33 \%$ & Low \\
\hline $75-85$ & 4 & $13,3 \%$ & Good \\
\hline $86-100$ & 1 & $0,03 \%$ & Very Good \\
\hline Total & 30 & $100 \%$ & \\
\hline
\end{tabular}

Source: Modified of Directorate of Vocational Development (2017: 13)

The indicator of success in this study is the improvement of students' cognitive accounting results shown by the achievement of MCC that has been established by the school that is equal to 75

\section{RESEARCH DISCUSSION}

\section{RESULT}

AND

The gamification that would be given to the students was the completion of the challenge game to achieve the objectives of mastering basic competence analyzing the adjusting entries with the following details in table 3:
Table 3. Description Each Gamification

\begin{tabular}{|l|l|}
\hline $\begin{array}{c}\text { The Type of } \\
\text { Gamification }\end{array}$ & Number of Questions \\
\hline $\begin{array}{l}\text { Jeopardy } \\
\text { Games }\end{array}$ & $\begin{array}{l}\text { Level 1 amounted to 9 } \\
\text { short field } \\
\text { Level 2 amounted to 9 } \\
\text { short field }\end{array}$ \\
\hline $\begin{array}{l}\text { Accounting } \\
\text { UNO Card }\end{array}$ & $\begin{array}{l}16 \text { short field for 1 set } \\
\text { UNO }\end{array}$ \\
\hline BINGO Games & 25 true false questions \\
\hline $\begin{array}{l}\text { Fun With } \\
\text { Accounting }\end{array}$ & $\begin{array}{l}20 \text { true false dan 15 } \\
\text { multiple choice }\end{array}$ \\
\hline
\end{tabular}

Source: Primary Data Processed

Implementation of the action began with the pre-test in each class, grade X AK 1 as the control class and X AK 2 as the action class. The results were presented in table 4 :

Table 4. Pre-test Results of Both Classes

\begin{tabular}{|c|c|c|c|}
\hline \multicolumn{2}{|c|}{$\begin{array}{c}\text { Action Class (X } \\
\text { AK 2) }\end{array}$} & \multicolumn{2}{c|}{$\begin{array}{c}\text { Control Class (X } \\
\text { AK 1) }\end{array}$} \\
\hline Description & Score & Description & Score \\
\hline Total Score & 1.448 & Total Score & 1508 \\
\hline Average & 48,27 & Average & 50,27 \\
\hline \multicolumn{2}{|c|}{ Significouldce of 2 tailed 0,435 } \\
\hline
\end{tabular}

Source: Primary Data Processed

There was no difference in ability between the two classes so that later could be used to compare students' ability after the action. The next step was implementing the Gamification Learning Method of cycle 1 in grade X AK 2. Post-test results of the first cycle of students were presented in table 5 :

Table 5. Post-Test Results of Cycle I Source: Primary Data Processed

There were 25 student or $83 \%$ had not

\begin{tabular}{|l|l|}
\hline \multicolumn{1}{|c|}{ Categories } & Value \\
\hline Low / not yet reached MCC & $<75$ \\
\hline Good & $75-85$ \\
\hline Very Good & $86-100$ \\
\hline
\end{tabular}

reached the minimum criteria. This happened because students were less serious about the challenge of the problem and drift in the mechanism of the game so that 
students joke a lot. Here were the results of data processing paired sample t-test using data application to determine whether there was gamification learning methods influence to learning results in cycle I:

Table 6. Paired Sample T-test Cycle I

\begin{tabular}{|c|c|c|c|}
\hline \multicolumn{4}{|c|}{ Paired Differences } \\
\hline Mean & $\begin{array}{c}\text { Std. } \\
\text { Deviation }\end{array}$ & $\begin{array}{c}\text { Std. Error } \\
\text { Mean }\end{array}$ & $\begin{array}{l}\text { Sig. } \\
(2- \\
\text { tailed })\end{array}$ \\
\hline$-16,267$ & 12,948 & 2,36397 &, 000 \\
\hline
\end{tabular}

Source: Primary Data Processed

It showed the sig value. $0.000<$ alpha 0,05 , so gamification learning method had an effect on improving learning results. Posttest results of the second cycle of students were presented in table 7 :

Table 7. Post-Test Results of Cycle II

\begin{tabular}{|c|c|c|c|}
\hline $\begin{array}{c}\text { The } \\
\text { Interval }\end{array}$ & $\mathbf{F}$ & $\mathbf{( \% )}$ & $\begin{array}{c}\text { The } \\
\text { Tendency }\end{array}$ \\
\hline$<75$ & 8 & $26,67 \%$ & Low \\
\hline $75-85$ & 13 & $43,3 \%$ & Good \\
\hline $86-100$ & 9 & $30 \%$ & Very Good \\
\hline Total & 30 & $100 \%$ & \\
\hline
\end{tabular}

Source: Primary Data Processes

Post-test indicated that the cognitive learning results of action class in cycle II had reached the established criteria, i.e. $>75$. There were 8 students who still had not reached the minimum criteria. The average score obtained by students was 80.3. Based on the implementation results of cycle II showed an increase in student cognitive learning results with some improvement from cycle I, so supporting Annie Lee (2015) research. The post-test results using data application were presented in table 8:

Source: Primary Data Processes

The total score of a sig. $0.000<$ alpha 0,05 , thus proved the influence of implementing The Gamification Learning Method to learning results in action class. The result of learning improvement data showed that Implementing This method could improve students' cognitive learning results by $66,3 \%$, so supported Endra Murti Sagoro (2016) research that this method could improve the ability of students more effectively. The following graph showed the improvement of student learning results through total and average values:

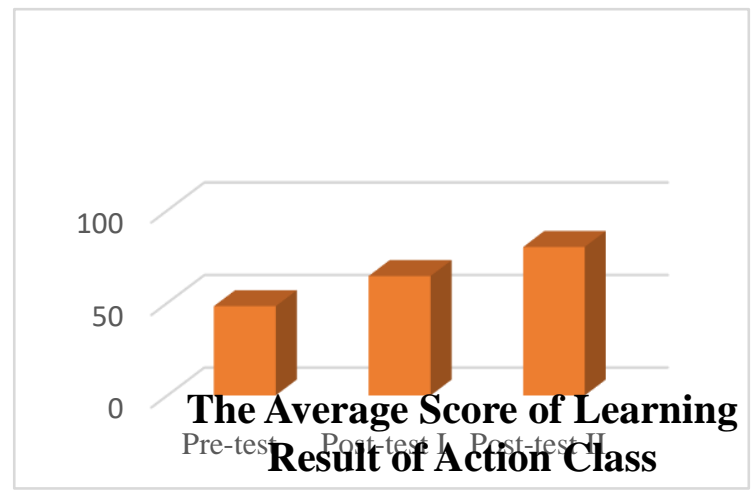

\section{Figure 2. A Comparison Diagram of The Average Score Of Students Action Class.}

In addition, to test the effectiveness of the use of Gamification Learning Method, it needed to be compared with the result of post-test grade X AK 1 as control class. The post-test results given to 30 students were presented in the following table:

Table 8. Post-test Result of Both Classes

\begin{tabular}{|c|c|c|c|}
\hline \multicolumn{2}{|c|}{$\begin{array}{c}\text { Action Class (X } \\
\text { AK 2) }\end{array}$} & $\begin{array}{c}\text { Control Class (X } \\
\text { AK 1) }\end{array}$ \\
\hline Description & Score & Description & Score \\
\hline Total Score & 2.408 & Total Score & 2.252 \\
\hline Average & 80,3 & Average & 75,1 \\
\hline \multicolumn{3}{|c|}{ Signifikansi 2 tailed 0,031 } \\
\hline
\end{tabular}

Source: Primary Data Processes

These results indicated that Sig. $0.031<$ alpha 0.05 , ie $<0.05$ indicated that there was a difference in ability between the two classes, so it could be concluded that the Gamification Learning Method was more effective than the teacher-centered method. The teacher-centered method accompanied by gamification will be more effective than just using the teacher-centered method, in accordance with Fitria's (2017) study which concludes the use of teacher-centered 
method was less effective when not accompanied by other methods.

Table 9. Paired Sample T-test Cycle II

\begin{tabular}{|c|r|c|l|}
\hline \multicolumn{4}{|c|}{ Paired Differences } \\
\hline \multirow{2}{*}{ Mean } & $\begin{array}{c}\text { Std. } \\
\text { Deviation }\end{array}$ & $\begin{array}{c}\text { Std. Error } \\
\text { Mean }\end{array}$ & $\begin{array}{l}\text { Sig. } \\
(2- \\
\text { tailed) }\end{array}$ \\
\hline$-15,73$ & 7,786 & 1,4214 &, 000 \\
\hline
\end{tabular}

conducted in groups, had rules, stimulated students to be interactive, and provided feedback in the form of quantitative value results in accordance with Kapp's (2012) opinion on guidelines for effective gamification activity. In the first cycle, the seven indicators of student responses arise during the learning process with the average score was $93,34 \%$ and rose to 95,23 in cycle II thus supporting previous research which concludes that gamification was one of the alternatives to improve students' intrinsic motivation and enthusiastically follow the learning process (Moncada \& Moncada, 2014; Schneep, 2014; Jusuf, 2016). Based on the above results, then the action was sufficient up to cycle II.

\section{CONCLUSION AND SUGGESTION Conclusion}

Based on the results of research and discussion that had been described, it could be concluded as follows:

1. Implementing the gamification learning methods could improve cognitive learning results of adjusting journal at grade X Accounting 2 students of SMK Negeri 1 Wonosari in the Academic Year of 2017/2018. The increase in student learning results is indicated by the increase of the average percentage in pre-test learning results, post-test I, and post-test II. The average pre-test score 48.27, post-test I 64.53, and post-test II 80.27. The overall improvement of $66,3 \%$ of student learning is calculated from pre-test and post-test II.

2. The gamification method is more effective for improving learning results compared to the teacher-centered method with a Sig. (2-tailed) of 0.031 .

3. Gamification method is able to improve student responses in the learning process.

\section{Suggestion}

Based on the results of research, the researcher gives suggestions as follows:

1. For Teacher

a. The teacher is expected to be able to combine this method with other learning methods. For example, the teacher can use a game mechanism to problem-solving exercises, so student will response it more enthusiasticly.

b. Teachers should motivate students to improve their independence in reading the material from the modules that has been given before the learning session.

c. Teachers should motivate students to follow the rules of the game so that the essence of the material is successfully delivered and the students can do the exercise.

2. For Further Researchers

a. Further research should be able to measure all aspects of the learning results, incude cognitive, affective, as well as psychomotoric.

b. Gamification methods can be applied to the basic competencies which is dominant in reasoning aspect, such as general journal, auditing, finansial accounting, tax, stock market, and cost accounting.

\section{REFERENCES}

Arikunto, S. (2015). Penelitian Tindakan Kelas. Jakarta: PT. Bumi Aksara.

Eneougu, N.D. \&Ejimonye, J.C. (2014). Teachers' Competence in Using Cooperative Learning Strategy in Teaching Economics in Secondary Schools in Anambra State Nigeria. Journal of Education and Practice. 
Fitriarachma, A. (2017). Efektivitas Penerapan Representasi Multipel Materi Asam Basa Terhadap Hasil Belajar Siswa. Skripsi. Yogyakarta: Universitas Negeri Yogyakarta. Vol. 5, No. 29, 165 .

Handani et al. (2016). Penerapan Konsep Gamification pada E-Learning untuk Pembelajaran Animasi 3 Dimensi. Jurnal Telematika Vol. 9 No. 1 Februari 2016.

Hikmah, N. (2017). The Development of Accounting UNO Card Game as an Accounting Learning Media in Basic Competence of adjusting Entries for Students in Class $X$ AK 3 SMK Negeri 7 Yogyakarta Academic Year 2016/2017. Skripsi. Yogyakarta: Universitas Negeri Yogyakarta.

Hunter, K. W. (2012). For The Win: How Game Thinking can Revolutionize Your Business. Philadelphia: Wharton Digital Press.

Jusuf, H. (2016). Penggunaan Gamification dalam Proses Pembelajaran. Jurnal TICOM Vol. 5, No. 1 September.

Kapp, K. M. (2012). Games, Gamification, and the Quest for Learner Engagement. Training and Development, 66, (6), 64-68.

Lodico, et al. (2010). Methods in Educational Research From Theory to Practice. America: Wiley.

Mills, E. G. (2014). Action Research: A Guide for The Teacher Research. London: Pearson Education.
Moncada, S.M. \& Moncada, T. P. (2014). Gamification of Learning in Accounting Education. Journal of Higher Education Theory and Practice Vol. 14 (3), 9.

Nurhayati, N. (2015). The Influence of Personal Information System Capabilities, Top Management Support, Training, and Education Program Performance of Accounting Information System Implications The Quality of Accounting Information in the Province of Islamic Banks of West Java. Research Journal of Finance and Accounting Vol.6, No. 3, 10.

Pratiwi, A. R. (2017). Pengembangan Game Akuntansi Berbasis RPG Maker sebagai Media Pembelajaran Akuntansi Siswa Kelas X SMK Negeri 1 Karanganyar Kabupaten Purbalingga. Skripsi. Yogyakarta: Universitas Negeri Yogyakarta.

Reeve et al.(2013). Principles of Accounting-Indonesia Adaptation. Jakarta: Salemba Empat.

Reichelt, A. L. (2015). Effects of Gamification: Analyzing Student Achievement, Mastery, and Motivation in Science Classroom. Tesis master, Montana State University, Montana.

Sagoro, E. M. (2016). Keefektifan Pembelajaran Kooperatif Berbasis Gamification Akuntansi pada Mahasiswa Non-Akuntansi. Jurnal Pendidikan Akuntansi Indonesia Vol XIV No. 2. 
Schnepp, J. C. (2014). Gamification Techniques for Academic Assessment. Bowling Green State UniversityScholarWorks@BGSU.

Siswoyo, D. (2013). Ilmu Pendidikan. Yogyakarta: UNY Press.

Sukiman. (2011). Pengembangan Sistem Evaluasi. Yogyakarta: Insan Madani.

Wood, L. C. \& Reiners, T. (2015). Gamification. Dalam M. Khosrow, Encyclopedia of Information Science and Technology, Third Edition (Hal. 3039). United States of America: IGI Global. 